\section{A STUDY OF ULCERATIVE COLITIS IN NEW ZEALAND, SHOWING A LOW INCIDENCE IN MAORIS}

\author{
BY
}

\section{R. D. WIGLEY, M.B., M.R.C.P., M.R.A.C.P.* \\ AND}

\section{B. P. MACLAURIN, M.B., M.R.C.P., M.R.A.C.P.}

The Public Hospital, Palmerston North, New Zealand

As no population study of non-specific ulcerative colitis has yet been completed, the incidence of this disease in the community is not known. Hospital in-patient records and national mortality statistics provide the only information available, but it is not usually possible to define the population from which hospital cases are drawn. Weiner and Lewis (1960) have summarized the published hospital data. Melrose's (1955) finding that colitis was more common in England than in Scotland has not been borne out by subsequent statistics. Jones (1956) noted a higher admission rate in the northeastern part of the United States than in the south, comparing the number of colitis patients admitted with the total number of admissions. Acheson (1959), studying the mortality of this disease in the United States, Canada, and England and Wales, found rather higher death rates in England and Wales than in the U.S.A. or Canada. The rate was higher in north-east and central U.S.A. than in the south. The urban rate was higher than the rural rate and there was a negative correlation with the distribution of dysentery. Acheson (1960), using the Veterans Administration Hospital statistics, was able to confirm Paulley's (1950) finding that colitis is more common in Jews. There is some evidence that colitis is less common in North-American negroes (Weiner and Lewis, 1960), but Acheson (1960) was unable to find convincing evidence of this from the Veterans Administration figures. The disease is said to be very rare in the North-American Indian (Bebchuk et al., 1961) and in negro children in the U.S.A. (Reinhart, 1961).

The familial incidence of colitis has been variously reported from 1 to $17 \%$, and there have been two reports of the disease affecting identical twins (Feder, 1938 ; Lyons and Postlethwait, 1948). Houghton and Naish (1958) described two families with three cases, and possibly four in one of them. They thought that this incidence was greater than could occur by chance, but McConnell (1960) thinks that the general incidence of colitis may have been underestimated. The present findings suggest that the incidence was overestimated. All the reported familial cases were blood relations, chiefly siblings, except for two married couples noted by Felsen and Wolarsky (1955) and another couple treated by J. B. W. Dunlop (1960, personal communication).

As New Zealand is a relatively closed community with a state medical service and all hospital discharge diagnoses have been filed under the international code since 1949, it is felt that useful information might be gained from a study of this material. We are indebted to Messrs. R. J. Rose and F. H. Foster, of the medical statistics branch at the Department of Health, New Zealand, for providing the relevant data.

\footnotetext{
*In receipt of an Empire Rheumatism Council Travelling Fellowship.
}

\section{Material}

It is estimated that at least $80 \%$ of patients treated in New Zealand hospitals are treated in public hospitals (Medical Statistics of New Zealand, 1958). The remaining $20 \%$ are treated in private hospitals, which have a strong bias towards surgical and short-term medical cases. A review of all New Zealand medical certificates for loss-of-work social security payments for 1960 showed 11 males with ulcerative colitis whose names did not appear in the public hospital records. Assuming an equal number of females, it appears that cases severe enough to be disabled but treated at home or in private hospitals would increase the public hospital admission figures for colitis by about $20 \%$. It is therefore improbable that a significant number of cases of ulcerative colitis severe enough to need hospitalization will not at some time appear in the public hospital records. Cases filed under category 572.2 (ulcerative colitis) of the International Classification of Disease were analysed, one entry only being made for each patient, irrespective of the number of admissions. Population figures were taken from the 1956 census, which was made at approximately the midpoint of the period under study.

Records filed under 572.2 from hospitals serving the southern part of the North Island of New Zealand were examined in detail during a study of the systemic complications of this disease. Cases were included as definite if there was a history of diarrhoea, with blood where an infective cause could reasonably be excluded, and only if there was sigmoidoscopic or radiological confirmation of the diagnosis. The area covered corresponds approximately to Wellington province, so that these cases will be referred to below as the Wellington group. The population of this area is 464,000 . It includes several small hospitals, but as the total number of patients treated in these hospitals was small and the diagnosis rate was not lower than in larger hospitals a significant error from this source is regarded as improbable.

Quarter-caste Maoris are classified as European, threequarter-caste as Maoris, and half-castes may declare themselves Maori or European. At the 1956 census $78 \%$ of those classified as Maoris in this way had threequarters or more Maori blood. For the whole of New Zealand in $1959,47 \%$ of Maori deaths occurred in hospital and $52 \%$ of European deaths. Post-mortem examination was made in $19 \%$ of Maori deaths and in $27 \%$ of European deaths. Though the Maori Death Act provides for death certification by persons other than medical practitioners or coroners, this provision is now hardly ever used. Overall figures suggest that Maoris avail themselves of the public hospital service as much as Europeans. Though Maoris in the more remote country areas may be admitted to hospital less often than Europeans, their hospital and mortality statistics are not thought significantly less accurate than the European figures (R. J. Rose, 1961, personal communication).

\section{Results \\ Wellington Group}

Table I shows that a definite diagnosis could be made in 205 cases and a probable diagnosis in 25. Some of the remainder were incompletely documented, and some had functional bowel conditions. Ten definite cases were excluded because the onset of the disease occurred outside the district under investigation. One of these 
TABLE I.-Diagnosis of the Wellington Group of Cases Definite diagnosis:

Radiological (usually supported $\{$ Right by sigmoidoscopic changes)

thological diagnosis only ..

Sigmoidoscopic evidence only

$$
\begin{aligned}
& \left\{\begin{array}{llc}
\text { Right colon } & \ldots & 1 \\
\text { Left \#̈ } & \ldots & 81 \\
\text { Left and right } & \cdots & 57^{*}
\end{array}\right\} \\
& \left.\ldots \begin{array}{ccc}
\text {. } & \cdots & 9
\end{array}\right\} \\
& \left\{\begin{array}{lll}
\text { With ulcers } & \cdots & 16 \\
\text { No ulcers seen } & \cdots & 41
\end{array}\right\}
\end{aligned}
$$

57 205

Probable colitis (other diagnoses improbable or information

incomplete) area studied colitis.

had entered the area for specialist medical care, but the other movements appeared to have been for social reasons.

\begin{tabular}{|c|c|c|c|c|c|c|c|c|c|c|}
\hline & \multirow{2}{*}{ Sex } & \multicolumn{8}{|c|}{ Age in Years } & \multirow{2}{*}{ Tot } \\
\hline & & 0 & 10 & 20 & $30-$ & 40 & $50-$ & 60 & $70+$ & \\
\hline $\begin{array}{l}\text { Proctitis with- } \\
\text { out ulcers }\end{array}$ & $\left\{\begin{array}{l}\mathbf{M} \\
\mathbf{F}\end{array}\right.$ & 1 & $\begin{array}{l}1 \\
2\end{array}$ & $\begin{array}{l}6 \\
2\end{array}$ & $\begin{array}{l}3 \\
4\end{array}$ & $\begin{array}{l}5 \\
2\end{array}$ & $\begin{array}{l}5 \\
2\end{array}$ & $\begin{array}{l}1 \\
0\end{array}$ & $\begin{array}{l}0 \\
1\end{array}$ & $\begin{array}{l}22 \\
14\end{array}$ \\
\hline $\begin{array}{l}\text { Proctitis with } \\
\text { ulcers } \ldots\end{array}$ & $\mathbf{M}$ & $\begin{array}{l}0 \\
1\end{array}$ & $\begin{array}{l}\mathbf{0} \\
\mathbf{0}\end{array}$ & $\begin{array}{l}1 \\
6\end{array}$ & 1 & $\begin{array}{l}1 \\
1\end{array}$ & $\begin{array}{l}1 \\
0\end{array}$ & $\begin{array}{l}1 \\
\theta\end{array}$ & $\begin{array}{l}0 \\
0\end{array}$ & $\begin{array}{l}5 \\
9\end{array}$ \\
\hline Colitis $\quad .$. & $\mathbf{M}$ & $\begin{array}{l}0 \\
1\end{array}$ & $\begin{array}{r}10 \\
5\end{array}$ & $\begin{array}{r}9 \\
22\end{array}$ & $\begin{array}{l}19 \\
22\end{array}$ & $\begin{array}{r}20 \\
9\end{array}$ & $\begin{array}{l}4 \\
5\end{array}$ & $\begin{array}{l}6 \\
6\end{array}$ & $\begin{array}{l}1 \\
0\end{array}$ & $\begin{array}{l}69 \\
70\end{array}$ \\
\hline $\begin{array}{c}\text { Colitis }+ \\
\text { ulcerative } \\
\text { proctitís }\end{array}$ & $\mathbf{M}$ & $\begin{array}{l}\mathbf{0} \\
\mathbf{2}\end{array}$ & $\begin{array}{r}10 \\
5\end{array}$ & $\begin{array}{l}10 \\
28\end{array}$ & $\begin{array}{l}20 \\
23\end{array}$ & $\begin{array}{l}21 \\
10\end{array}$ & $\begin{array}{l}5 \\
5\end{array}$ & $\begin{array}{l}7 \\
6\end{array}$ & $\begin{array}{l}1 \\
0\end{array}$ & $\begin{array}{l}74 \\
79\end{array}$ \\
\hline All cases $\ldots$ & $\left\{\begin{array}{l}\mathrm{M} \\
\mathrm{F}\end{array}\right.$ & $\begin{array}{l}1 \\
3\end{array}$ & $\begin{array}{r}11 \\
7\end{array}$ & $\begin{array}{l}16 \\
30\end{array}$ & $\begin{array}{l}23 \\
27\end{array}$ & $\begin{array}{l}26 \\
12\end{array}$ & $\begin{array}{r}10 \\
7\end{array}$ & $\begin{array}{l}8 \\
6\end{array}$ & $\begin{array}{l}1 \\
1\end{array}$ & $\begin{array}{l}96 \\
93\end{array}$ \\
\hline
\end{tabular}

Table II shows the sex-and-age distribution of the definite cases at the time of onset of symptoms.

TABle II.-Sex-and-Age Distribution of the Wellington Cases

*Test of male/female difference in colitis + ulcerative proctitis group: $\chi^{2} \mathrm{c}=13 \cdot 35$ for 5 d.f., $P=0.02$.

Five family trees are shown in the accompanying Diagram. The average number of siblings in New Zealand families is estimated to be three (R. J. Rose, 1961 , personal communication). It is possible to calculate, under the null hypothesis, that there is a one-in-ten chance of two propositi appearing in one family in the estimated 155,000 families involved. In fact, two propositi appear in each of two families. In two further families there were two siblings with definite colitis not requiring hospitalization during the study period. In a fifth family one case occurred in each of three generations (see Diagram).

The urban and rural distribution of 192 cases where sufficient information was available are shown in Table III. The incidence in towns of from 4,000 to

\begin{tabular}{|c|c|c|c|c|}
\hline \multirow{2}{*}{\multicolumn{2}{|c|}{-}} & \multicolumn{3}{|l|}{ Cases } \\
\hline & & Population & $\begin{array}{l}\text { Colitis } \\
\text { Cases }\end{array}$ & $\begin{array}{c}\text { Cases per } \\
100,000\end{array}$ \\
\hline \multirow{2}{*}{\multicolumn{2}{|c|}{ 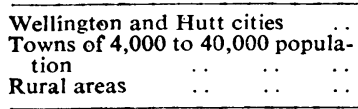 }} & 224,350 & 90 & $40 \cdot 2$ \\
\hline & & $\begin{array}{r}106,117 \\
134,053 \\
\end{array}$ & $\begin{array}{l}60 \\
42 \\
\end{array}$ & $\begin{array}{r}56.5 \\
31.8 \\
\end{array}$ \\
\hline & .. & 464,520 & 192 & $\overline{41 \cdot 3}$ \\
\hline
\end{tabular}
40,000 inhabitants is nearly double the rural incidence $\left(\chi^{2}{ }_{c}=8.24, P=0.01\right)$. The difference between all towns

TABLE III.--Urban and Rural Distribution of 192 Wellington above 4,000 and rural areas is small but is significant $\left(\chi_{0}^{2}=4.22, \mathrm{P}=0.04\right)$.

\section{Maori Incidence}

There were no Maoris in the Wellington group. Analysis of the hospital cases for the whole of New Zealand according to sex-and-age distribution at the time of first admission to hospital is shown in Table IV. Only three Maoris appeared among these cases. On
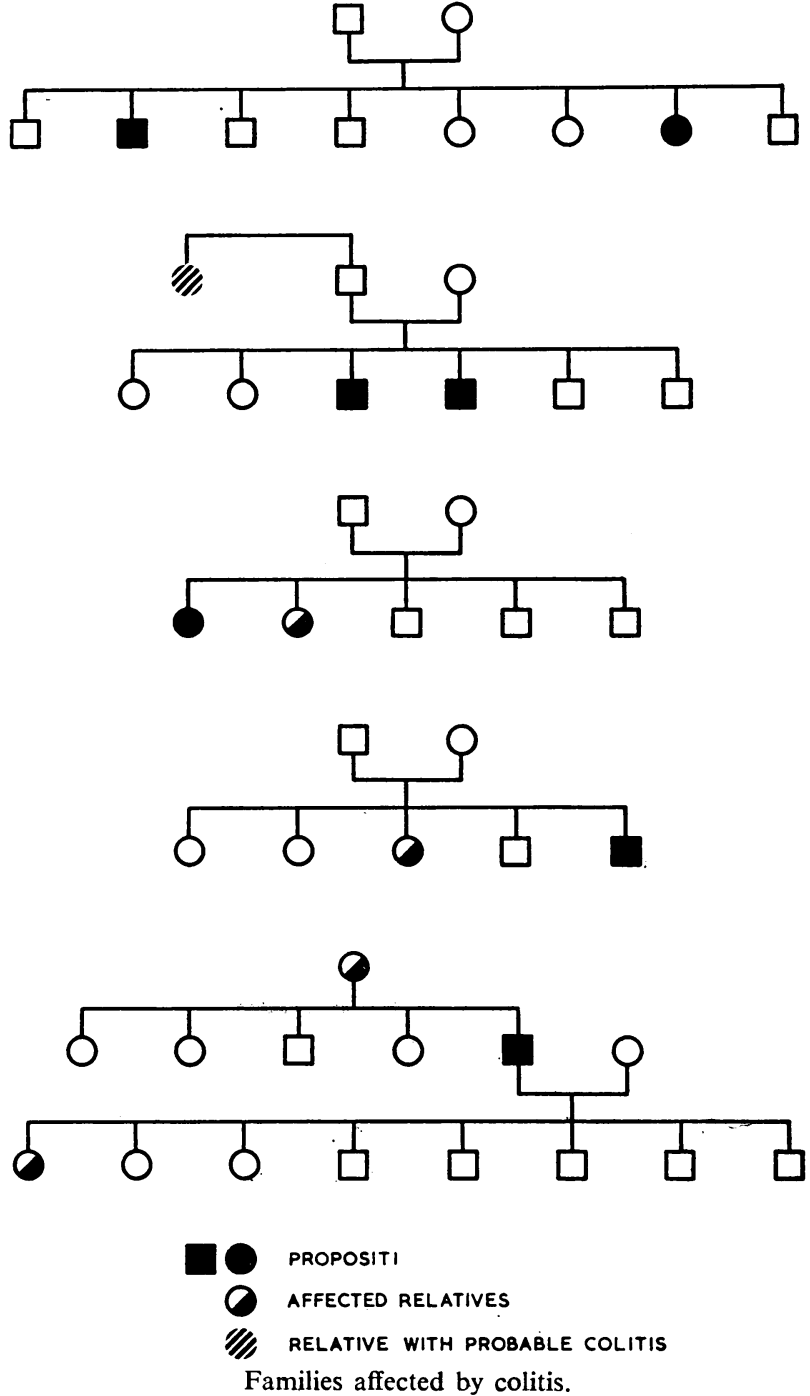

examining the relevant case records it was found that one had been misfiled and did not have colitis; the second had proctitis without ulcers and was a threequarter-caste Maori ; and the third had definite colitis and was probably a full Maori but has not so far been traced to check this point. The difference in incidence

\begin{tabular}{|c|c|c|c|c|c|c|c|c|c|c|c|}
\hline & Sex & 0 & 10 & $20-$ & $30-$ & $40-$ & 50 & 60 & 70 & 80 & Total \\
\hline \multirow{2}{*}{5 years $-1954-8$} & $\underset{\mathbf{F}}{\mathbf{M}}$ & $\begin{array}{l}5 \\
2\end{array}$ & $\begin{array}{l}32 \\
15\end{array}$ & $\begin{array}{l}54 \\
73\end{array}$ & $\begin{array}{r}64 \\
75 \\
\end{array}$ & $\begin{array}{l}47 \\
63 \\
\end{array}$ & $\begin{array}{l}39 \\
44 \\
\end{array}$ & $\begin{array}{l}22 \\
41\end{array}$ & $\begin{array}{l}20 \\
13 \\
\end{array}$ & $\begin{array}{l}1 \\
4\end{array}$ & $\begin{array}{l}284 \\
330\end{array}$ \\
\hline & $\mathbf{M}+\mathbf{F}$ & 7 & 47 & 127 & 139 & 110 & 83 & 63 & 33 & 5 & 614 \\
\hline $\begin{array}{l}\text { Age-sex specific rates } \\
100,000\end{array}$ & $\underset{\mathbf{F}}{\mathbf{M}}$ & $\begin{array}{l}0 \cdot 39 \\
0 \cdot 16\end{array}$ & $\begin{array}{l}3 \cdot 60 \\
1 \cdot 75\end{array}$ & $\begin{array}{r}7 \cdot 27 \\
10 \cdot 42\end{array}$ & $\begin{array}{r}8 \cdot 54 \\
10 \cdot 17\end{array}$ & $\begin{array}{l}6 \cdot 88 \\
9 \cdot 43\end{array}$ & $\begin{array}{l}7 \cdot 56 \\
8 \cdot 71\end{array}$ & $\begin{array}{r}6 \cdot 37 \\
10 \cdot 38\end{array}$ & $\begin{array}{l}8 \cdot 84 \\
4 \cdot 97\end{array}$ & $\begin{array}{l}1 \cdot 54 \\
4 \cdot 78\end{array}$ & \\
\hline
\end{tabular}
between Maori and European is highly significant (Table V). The predominance of young people in the

TABLE IV.-Hospital Deaths and Discharges for all New Zealand, 1954-8 
TABLE V.-Comparison of Frequency of Colitis in Hospital In-patients, 1954-8, Inclusive, With Total Population at Risk

\begin{tabular}{|c|c|c|c|}
\hline \multicolumn{2}{|c|}{ Race } & Colitis & No Colitis \\
\hline $\begin{array}{l}\text { Maori ... } \\
\text { European }\end{array}$ & $\ldots$ & $\begin{array}{r}3 \\
611\end{array}$ & $\begin{array}{r}137,149 \\
2,036,300\end{array}$ \\
\hline
\end{tabular}

Maori population does not appear to play a part, as the difference is still definite if a separate examination of the third to fifth decades, in which the majority of cases in Europeans occur, is made (Table VI).

TABLE VI.-Comparison of Frequency of Hospital Admission for Colitis, 1954-8, Inclusive, With the Population at Risk from 20 to 49 Years of Age

\begin{tabular}{|c|c|c|c|c|}
\hline \multicolumn{3}{|c|}{ Race } & Colitis & No Colitis \\
\hline $\begin{array}{l}\text { Maori } \\
\text { European }\end{array}$ & $\ldots$ & 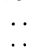 & $\begin{array}{r}3 \\
376\end{array}$ & $\begin{array}{r}47,233 \\
808,618\end{array}$ \\
\hline
\end{tabular}

\section{Mortality}

Table VII shows the mortality for all New Zealand for the five-year period 1954-8. There is a significant predominance of women, but the average age does not differ significantly in men and women. The overall negative relation to the incidence of dysentery, the higher incidence in towns where hygiene is better, and the infrequent involvement of both husband and wife suggest that other factors determine whether an individual will develop the disease or not. The occurrence of the disease in relatives living apart-for example, family 5 in Diagram, where the grandmother died of the disease in England before the son and granddaughter developed the disease in New Zealand, and other instances mentioned by Houghton and Naish (1958) - make non-genetic causes less probable. Paulley (1950) suggests that the familial incidence has a psychosomatic basis, but even if this is so the psychological predisposition could be genetic rather than environmental. The absence of obvious psychological upset in many patients and the psychological recovery of many who have the somatic disease removed surgically (Aylett, 1960) suggests that psychological disturbances are precipitating or secondary rather than causative factors in individuals predisposed to develop the disease. The predominance of mothers over fathers in the reported family histories may be due to the higher incidence of severe disease in women, more likely to be recorded in routine case records, rather than to emotional dependence on the mother as suggested by Paulley (1950).

TABle VII.-Ulcerative Colitis Mortality for New Zealand, 1954-8 Inclusive. (Age specific rates per 100,000 below)

\begin{tabular}{|c|c|c|c|c|c|c|c|c|c|c|c|c|c|c|c|c|c|c|}
\hline \multicolumn{3}{|c|}{ Age (Years): } & 0 & $5-$ & 10 & $15-$ & 20 & $25-$ & $30-$ & $35-$ & 40 & $45-$ & 50 & $55-$ & 60 & $65-$ & $70-$ & $75-$ \\
\hline $\begin{array}{l}\text { Male } \\
\text { Female }\end{array}$ & $\ldots$ & $\begin{array}{l}\cdots \\
\cdots\end{array}$ & $\begin{array}{l}1 \\
0\end{array}$ & $\begin{array}{l}0 \\
0\end{array}$ & $\begin{array}{l}0 \\
1\end{array}$ & $\begin{array}{l}2 \\
1\end{array}$ & $\begin{array}{l}4 \\
2\end{array}$ & $\begin{array}{l}3 \\
4\end{array}$ & $\begin{array}{l}3 \\
5\end{array}$ & $\begin{array}{l}2 \\
6\end{array}$ & $\begin{array}{l}2 \\
2\end{array}$ & $\begin{array}{l}1 \\
8\end{array}$ & $\begin{array}{l}3 \\
4\end{array}$ & $\begin{array}{l}1 \\
5\end{array}$ & $\begin{array}{l}4 \\
2\end{array}$ & $\begin{array}{l}1 \\
7\end{array}$ & $\begin{array}{l}1 \\
8\end{array}$ & $\begin{array}{l}6 \\
3\end{array}$ \\
\hline Total & . & .. & 1 & 0 & 1 & 3 & 6 & 7 & 8 & 8 & 4 & 9 & 7 & 6 & 6 & 8 & 9 & 9 \\
\hline $\begin{array}{l}\text { Male } \\
\text { Female }\end{array}$ & 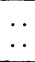 & $\begin{array}{l}\cdots \\
\cdots\end{array}$ & $\begin{array}{l}0 \cdot 17 \\
0\end{array}$ & $\begin{array}{l}0 \\
0\end{array}$ & $\begin{array}{l}0 \\
0 \cdot 24\end{array}$ & $\begin{array}{l}0.55 \\
0.28\end{array}$ & $\begin{array}{l}1.26 \\
0.66\end{array}$ & $\begin{array}{l}0.80 \\
1 \cdot 16\end{array}$ & $\begin{array}{l}0.80 \\
1.39\end{array}$ & $\begin{array}{l}0.59 \\
1.73\end{array}$ & $\begin{array}{l}0.59 \\
0.59\end{array}$ & $\begin{array}{l}0.31 \\
2.61\end{array}$ & $\begin{array}{l}1.11 \\
1.56\end{array}$ & $\begin{array}{l}0.44 \\
2 \cdot 16\end{array}$ & $\begin{array}{l}2.28 \\
0.98\end{array}$ & $\begin{array}{l}0.61 \\
3.74\end{array}$ & $\begin{array}{l}0 \cdot 74 \\
5 \cdot 25\end{array}$ & $\begin{array}{l}3.92 \\
1.60\end{array}$ \\
\hline T•tal & . & $\ldots$ & 0.08 & 0 & 0.11 & 0.42 & 0.96 & 0.97 & 1.09 & $1 \cdot 17$ & 0.59 & 1.44 & $1 \cdot 33$ & $1 \cdot 31$ & 1.59 & $2 \cdot 28$ & $3 \cdot 14$ & $2 \cdot 65$ \\
\hline
\end{tabular}

Test of overall sex difference in the number of deaths: $\quad \chi^{2} \mathrm{c}=5.75$ for 1 d.f., $\mathrm{P}=0.02 . \quad$ Test of difference in age distribution of deaths: $\quad \chi^{2} \mathrm{c}=3.94$ for 2 d.f, $P=0 \cdot 15$.

mortality of 0.9 per 100,000 at risk is similar to that in the U.S.A., Canada, and England and Wales (Acheson, 1959). No Maori deaths were recorded in this period or in the subsequent year.

\section{Discussion}

The incidence of colitis severe enough to warrant hospitalization in New Zealand can be estimated to be five to six new cases per 100,000 per annum, as the Wellington group (including probable cases) provided 51 cases per 100,000 for a ten-year period; and the national hospital figures (which include 3 to $5 \%$ of dubious diagnoses) provide 30 cases per 100,000 for a five-year period. The incidence of colitis not requiring hospitalization is unknown, so that it is not yet possible to include relatives in this category in calculation of probabilities of familial incidence. As both this study and that of Houghton and Naish (1958) were retrospective, ascertainment of affected relatives was almost certainly incomplete. As when two members of a family are affected by a disease they are more likely to be included in a study of this kind, too much reliance must not be placed on the findings until the total incidence in the community and the actual family size can be ascertained. It has been argued that the familial incidence is due to psychological factors, infections, heredity, or a combination of these.

The evidence that bowel infection can precipitate colitis is strong (Felsen and Wolarsky, 1955), but the
The low incidence in Maoris could be attributed to a lower diagnosis rate, as they tend to be stoical and call in medical aid rather late, especially in country areas, but Maoris tend to avail themselves of the Public Hospital Service more than Europeans (R. J. Rose, 1961, personal communication). A similar study of the incidence of hospital admissions for coronary disease (C. Crawford, 1961, unpublished observations) shows no difference in admission rate between Maoris and European males after standardization for age and population at risk. The alternative explanation that coronary disease is more common in the Maori but the proportion admitted to hospital is lower seems improbable, as the mortality statistics show no racial difference for males (Rose, 1959). Further, if colitis in Maoris was neglected an occasional case should appear in the death statistics. The difference is therefore thought to be a genuine one, possibly with a genetic basis.

ABO blood group and secretor factor studies show no correlation with colitis (Winstone et al., 1960 ; Smith and Truelove, 1961), so the difference cannot be related to the low frequency of $\mathrm{B}$ and $\mathrm{AB}$ types in the Maori (Douglas and Staveley, 1960). Boyd et al. (1961) have found a high incidence of rhesus type $\mathrm{C} \mathrm{C}$ in a preliminary study of colectomy cases. If confirmed this would add to the evidence for a genetic factor in this disease. It does not explain the low incidence in Maoris, as they do not show a low proportion of C C (Staveley and Douglas, 1958). 
Matsunaga (1958) believes colitis to be quite rare in Japan, though interpretation of his findings is difficult, as amoebic dysentery occurs in Japan and the marked predominance of males suggests that they are not a typical group of colitis cases. Colitis has been regarded as very rare in India, but Prakash (1961, personal communication) has diagnosed 26 cases by careful follow-up of cases failing to respond to anti-amoebic treatment.

Amoebic dysentery and lymphogranuloma venereum hardly ever occur in New Zealand and infectious forms of syphilis are rare, so that diagnosis of non-specific colitis is relatively simple. Shiga and Flexner dysentery were responsible for five and six hospital admissions respectively in 1958. Sonne infection is more common (67 admissions) but should not cause rectal bleeding in adults, and so should not give rise to diagnostic difficulty. Maori standards of housing and hygiene are lower than those of Europeans (1956 Census), so that a higher incidence would be expected if the disease had an infectious cause.

The overall sex difference in the national cases does not quite reach significance, but analysis of sex-and-age distribution shows a significant predominance of males in the first two decades, and of females from the third to the seventh decade. The Wellington group shows no overall sex difference, but if males with proctitis without ulcers are excluded there is a significant predominance of women, the main difference being in the third decade. The $1 \%$ majority of males in the population of New Zealand must diminish rather than exaggerate the sex difference. Thus it appears that hospital admission is more frequent in women over 20 years of age and that the greater frequency of the milder form of the disease in males may account for the smaller number of deaths. Child-bearing is generally thought to aggravate colitis (Bacon, 1958), and this factor may account for the difference. The disparity between hospital and mortality statistics could be due to women more often declining admission and dying at home, but this seems quite improbable.

Truelove (1961) has been able to induce recurrences of colitis by withdrawing and reintroducing milk into the diet of some of his cases, supporting Andreson's (1942) view that colitis is due to an external allergen. Taylor and Truelove (1961) have shown agglutination of red cells coated with milk proteins in higher titre in colitis cases than in controls. This would not seem to account for the low incidence in Maoris, as the available evidence (McLaughlin and Wilson, 1945) suggests that their milk intake does not fall far short of that of the European (M. Bell, 1961, personal communication). The possibility of a common aetiology with the collagen diseases and the question of auto-immunity will be discussed elsewhere.

\section{Summary and Conclusions}

A study of the New Zealand public hospital statistics and a detailed study of all case records classified as ulcerative colitis in the southern part of the North Island of New Zealand show an annual hospital admission rate of 5 to 6 cases per 100,000 and a mortality rate of 0.9 per 100,000 Europeans at risk.

Only two definite cases in Maoris were found, the difference in incidence being much greater than could occur by chance, and no Maori deaths were recorded in this period. Evidence is presented that this is a genuine difference.
The familial incidence is thought to be greater than could occur by chance, but a detailed family study is indicated.

The epidemiological evidence is not consistent with the infective theory of causation of colitis.

There is no overall sex difference in hospital admissions, but males predominate up to 20 years and females thereafter. More females have the ulcerative form of the disease and more deaths are recorded in females, though the age at death does not differ from that of the males.

We are indebted to Mr. A. Glenday, of the Department of Scientific and Industrial Research, Palmerston North, for the statistical analysis; to Mr. N. W. Please, of University College, Dr. J. S. Lawrence, Dr. E. J. Holborow, and Professor E. G. L. Bywaters for constructive criticism of this paper ; and to the medical superintendents of the various hospitals concerned and Dr. H. B. Turbott, Director General of Health, New Zealand, for permission to publish this material.

REFERENCES

Acheson, E. D. (1959). J. chron. Dis., 10, 469.

Andreson, A. F. R. (1942). Amer. J. dig. Dis., 9, 91.

Aylett, S. (1960). Ann. roy. Coll. Surg. Engl., 27, 260.

Bacon, H. E. (1958). Ulcerative Colitis. Lippincott, Philadelphia.

Bebchuk, W., Rogers, A. G., and Downey, J. L. (1961). Gastroenterology, 40, 138.

Boyd, W. C., Heisler, M., and Onowan, E. (1961). Nature (Lond.), 190, 1124 .

Brooke, B. N. (1954). Ulcerative Colitis and Its Surgical Treatment. Livingstone, Edinburgh.

Census, New Zealand (1956). Volume 10, Government Printer, Wellington.

Douglas, R., and Staveley, J. M. (1960). J. Polynes. Soc., 69, 34.

Feder, I. A. (1938). Amer. J. dig. Dis., 5, 239.

Felsen, J., and Wolarsky, W. (1955). Gastroenterology, 28, 412.

Houghton, E. A. W., and Naish, J. M. (1958). Gastroenterologia $(B), 89,65$.

Jones, C. A. (1956). Amer. J. Gastroent., 26, 679.

Lyons, C. K., and Postlethwait, R. W. (1948). Gastroenterology, 10,545 .

McConnell, R. B. (1960). Gut, 1, 273

McLaughlin, E. C. G., and Wilson, I. (1945). N.Z. med. J., 44, 93.

Matsunaga, F. (1958). World Congress of Gastroenterology, p. 955. Williams and Wilkins, Baltimore.

Medical Statistics of New Zealand (1958). Government Printer, Wellington.

Melrose, A. G. (1955). Gastroenterology, 29, 1055.

Paulley, J. W. (1950). Ibid., 16, 566.

Reinhart, J. B. (1961). J. Dis. Child., 101, 401.

Rose, R. J. (1959). European-Maori Standards of Health, Government Printer, Wellington.

Smith, R. S., and Truelove, S. C. (1961). Brit. med. J., 1, 870 Staveley, J. M., and Douglas, R. (1958). J. Polynes. Soc., 67,

Taylor, K. B., and Truelove, S. C. (1961). Brit. med. J., 2, 924.

Truelove, S. C. (1961). Ibid., 1, 154

Weiner, H. A., and Lewis, C. M. (1960). Amer. J. Dig. Dis., $5,406$.

Winstone, N. E., Henderson, A. J., and Brooke, B. N. (1960). Lancet, 2,64 .

The British Standards Institution has recently published a glossary which defines some 700 terms in common use by those who design, teach the theory of, make, or handle ophthalmic lenses and spectacle frames. The glossary (B.S. $3521: 1962$ : Glossary of terms relating to ophthalmic lenses and spectacle frames) is the work of an expert committee representing such bodies as the Association of Dispensing Opticians. Guild of British Dispensing Opticians, British Medical Association, Faculty of Ophthalmologists, Federation of Manufacturing Opticians, Joint Committee of Ophthalmic Opticians, Association of Contact Lens Manufacturers, Association of Contact Lens Practitioners, Scottish National Committee of Ophthalmic Opticians, and Associated Manufacturers of Solid Bifocals. (Copies may be obtained from the B.S.I. Sales Branch, 2 Park Street, London W.1. Price 20s. each; postage extra to nonsubscribers.) 